\title{
Camel Milk Composition, Udder Health and Effect of Different Storage Times and Temperatures on Raw Milk Quality Using Camel Milking Machine "StimuLactor"
}

\section{Kaskous S.}

Department of Research and Development, Siliconform, Schelmengriesstrasse 1, D-86842 Türkheim, Germany. Email:skaskous@siliconform.com

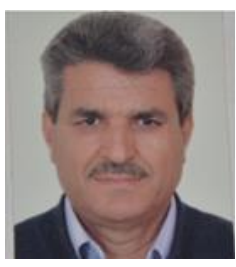

Abstract

Camel milk is considered one of the most valuable food sources for people in arid and semi-arid areas and is in increasing demand in many European countries and North America. The objective of this study was to investigate the camel milk composition, udder health and effect of different storage times and temperatures on raw milk quality using camel milking machine "StimuLactor" (ST-C). This work was carried out in the department of research and development of Siliconform Türkheim, Germany. Five one-humped dromedary lactating camels were used in this experiment. Milk samples were collected and fat, Protein, Lactose, Somatic cell count (SCC) and Bacterial count (BC) were determined. In none of the tested milk samples pathogenic bacteria could be shown, i.e. all quarters were healthy during the study period. The mean contents of fat, protein, lactose, SCC and BC of milk samples were $2.92 \pm 0.07 \%, 2.28 \pm 0.01 \%, 3.91 \pm 0.02 \%, 126.43 \pm 7.21 \mathrm{x}$ 103 cells $/ \mathrm{ml}$ and $23.88 \pm 0.57 \times 103$ Bacteria/ml, respectively. After $24 \mathrm{~h}$ at room temperature or $48 \mathrm{~h}$ at 4 degree a refrigerator, storing raw milk samples had no significant changes in the milk composition and -quality. In Conclusion, a good safe raw camel milk with normal composition was obtained if hygienic measures were taken into consideration in the farm and by using the camel milking machine for milk removal. Furthermore, we could store the raw camel milk for $24 \mathrm{~h}$ at room temperature or for $48 \mathrm{~h}$ in the refrigerated temperature without any hygienic quality problems, and all milk components did not significantly change.

Keywords: Dromedary camel, Milk composition, StimuLactor, Udder health, Milk quality, Milk storage.

Citation | Kaskous S. (2019). Camel Milk Composition, Udder Health and Effect of Different Storage Times and Temperatures on Raw Milk Quality Using Camel Milking Machine "StimuLactor". Agriculture and Food Sciences Research, 6(2): 172-181. Agriculture

Received: 2 April 2019

Revised: 13 May 2019

Accepted: 18 June 2019

Published: 29 July 2019

Licensed: This work is licensed under a Creative Commons

Attribution 3.0 License (cc) EY

Publisher: Asian Online Journal Publishing Group

\section{Contents}

1. Introduction interests regarding the publication of this paper.

Transparency: The author confirms that the manuscript is an honest, accurate, and transparent account of the study was reported; that no vital features of the study have been omitted; and that any discrepancies from the study as planned have been explained.

Ethical: This study follows all ethical practices during writing. 


\section{Contribution of this paper to the literature}

This study gives us very important information about raw camel milk composition under German condition and how to produce a good quality of raw camel milk. For that, hygienic measures and using the camel milking machine "StimuLactor" for milk removal are important factors. In addition, this study shows, how you can store the raw camel milk without any significant change in the raw camel milk quality.

\section{Introduction}

Camel milk and its products have nutritional and medical properties that make them valuable foods. In many regions in Asia and Africa, camel milk are used to treat some diseases and to combat health problems such as gastrointestinal disorders, sugar diseases, food allergy, psoriasis, hepatitis C and B, autism and tuberculosis [1-3]. Traditionally, camel milk is consumed raw by the pastoralists without any heat treatments in order to exploit the healthy milk properly [4-8]. However, camel milk is an excellent culture medium for the growth of microorganisms $[5,9,10]$ and non-heat treated milk and raw milk products are considered a major factors responsible for illnesses caused by food borne pathogens $[10,11]$. The milk of a healthy udder is practically sterile [12] and it contains a very low concentration of microorganisms, usually less than $10 \times 10^{2}$ colony forming units of total bacteria per ml milk [10]. However, the milk is contaminated only with the passage of the teat canal with bacteria [9]. Entering bacteria into the milk may come from the dirty udder-and teat-surfaces, the stall, the feed, the milker, the air, the water, the milking equipment and finally during storage and transport. Among the microbe population, some categories are more dangerous such as pathogenic bacteria, because they may transmit diseases to humans or cause defects in the final product. The rate of multiplication of microbes in the milk depends mainly on the initial number of bacteria, the storage temperature and storage duration.

Our challenge is how to provide safe raw camel milk to consumer at any time or to the dairy industry for processing. Sometimes, camel herds are located so far from the cities and the camel milk must be stored for many hours before reaching the consumer.

The aim of this study was to investigate the composition of camel milk and total bacteria under German conditions, in which green grass or hay are available all year round. Nevertheless, it is highly humid and cold in the winter. Several studies dealing with the chemical composition of Camel milk were conducted around the world but not in Germany. Furthermore, changes in the milk composition and total Bacteria count in the raw camel milk was investigated after different storage time and temperature. Many people around the world want to drink camel milk fresh for healthy reason. Therefore, the best storage time and temperature was applied in this study after using machine milking technique "StimuLactor", which contributed to the stability of milk quality and composition.

\section{Material and Methods}

\subsection{Location}

This work was carried out in the Department of Research and Development of Siliconform Company located in Türkheim, Germany.

\subsection{Animals and Management}

In this study, five one-humped Dromedary lactating camels in the late stage of lactation were used and were available in the department of research and development. The camels were kept outdoor most of the time. However, at night and in the cold winter they were kept in the barn using the loose housing system. Camels fed primarily on pasture and they were also provided with hay in addition to vitamins and minerals supplement. Meanwhile, drinking water was available at all time.

\subsection{The Used Milking System}

ST-C was used in this work, which developed in the Siliconform company, Türkheim, Germany [13] (www.siliconform.com). This milking system has the following technical characteristics: It is based on a quarter individual milking system, which means that milking cups work independently from each other, without a claw. However, the system provides periodic air inlet into the teat cups. Furthermore, the working vacuum level is set to $36 \mathrm{kPa}$ and sequential pulsation (25\% each quarter) was adopted. The pulsation rate was $90 \mathrm{cycles} / \mathrm{min}$ with a 65:35 pulsation ratio during the milking time. In addition, the system was equipped with a silicone liners and it had a very special pre-stimulation program and an excellent cleaning and sanitary process.

\subsection{The Milking Routine}

The camels were milked once a day at 11:00 am with a unit milking machine ST-C, and without the presence of calves during the milking process. The milking routine started with a pre-milking preparation, in which the teats were cleaned with a wet udder tissue and afterwards they were dried using another clean tissue. Afterwards, the teat cups of the milking unit were individually or in pairs attached manually to the teats. Subsequently, the milking process started on the control display and the pre-stimulation began. The pre-stimulation was programmed so that the teats were intensively stimulated with a normal pulse rate $(90 \mathrm{cycles} / \mathrm{min})$ and a reduction in the suction phase (b-phase) of $10 \%$ over a period of 90 sec. Simultaneously, intensive movement of the teat cups were regulated as an additional stimulation which is operated by an actuator. It was an arm on which four milk tubes are situated. During the pre-stimulation and the milking time, this arm was moving up and down. This movement was transferred to the teat cups and made the teats erecting. After stimulation time, the main milk phase began and the milk flow was observed on the display. When the milk flow has decreased to a certain level, the milking process was automatically stopped by detaching the milking unit. After milking process is completed, the milking unit was cleaned and the milk volume was immediately measured using a graduated cylinder. 


\subsection{Milk Sample Collection}

Milk samples were collected weekly during a period of 8 weeks and qualitative examinations were done. Three groups of milk samples were collected, namely:

\subsubsection{Group 1 (Gr.1)}

Milk sampling used to detect the presence of pathogen bacteria in the udder: Milk samples were taken from each quarter after the udder being washed, dried, disinfected, the first stripping was removed, then the sample tube was opened and about 5 to $10 \mathrm{ml}$ of milk was taken from each quarter in each tube. Afterward, the tubes were immediately closed, Maintained in a cool box at $8 \mathrm{C}^{\circ}$ using ice cubes and transported to the laboratory for the pathogenic bacteria determination.

\subsubsection{Group 2(Gr.2)}

Milk sampling to determine the milk composition and milk quality: After machine milking, milk samples were taken in duplicate, ca. $25 \mathrm{ml}$ in each in special tubes with preservatives for the determination of fat, protein, Lactose, SCC and other tubes with other preservatives for determination of BC.

\subsubsection{Group 3 (Gr.3)}

Milk sampling to determine the effect of storage times and temperatures on raw milk parameters: Milk samples were taken and divided as shown in the Table 1 :

Table-1. Storage of raw milk in different times and temperatures

\begin{tabular}{l|c|c}
\hline Studied time & Room temperature $\left(\mathbf{2 4} \mathbf{C}^{\circ}\right)$ & Refrigerator Temperature $\left(\mathbf{4} \mathbf{C}^{\circ}\right)$ \\
\hline Immediately after milking (zero time, $\mathrm{O})$ & $\mathrm{X}$ & $\mathrm{X}$ \\
\hline After 2 hours of milking & $\mathrm{X}$ & $\mathrm{X}$ \\
\hline After 6 hours of milking & $\mathrm{X}$ & $\mathrm{X}$ \\
\hline After 24 hours of milking & $\mathrm{X}$ & $\mathrm{X}$ \\
\hline After 48 hours of milking & $\mathrm{X}$ & $\mathrm{X}$ \\
\hline Source: Kaskous, $\mathrm{S}$ & & \\
\hline
\end{tabular}

After the storage times and temperatures shown in the table, the milk samples were taken and analyzed for fat, protein, lactose, SCC and BC.

\subsection{Milk Sample Analysis}

Milk samples Gr.1 in the individual quarters were examined using methods MET-EGD-001-005. The investigation was applied in the Animal health service Bavaria e.V. However, the determination of the milk parameters in milk sampling Gr. 2 und Gr. 3, they were performed on: Fat and protein, routine procedure of IR spectroscopy was used. Nevertheless, lactose content was determined using the routine methods MPR-MET 01. SCC of the milk was determined by fluorescence optical counting (ASU Lo1.01-1). While, BC was determined by Flow Cytometric enumeration of microorganisms (ASU L01.01-7). All of the milk samples were analyzed in Milchprüfring Bavaria e.V.

\subsection{Data Analysis}

The data were subjected to statistical analysis of variance using SAS program package [14] and the least square means were compared using F-Test for the influence of the week or the time and temperature on milk quality and composition. The results were shown as LSM \pm SE.

\section{Results and Discussion}

\subsection{Examination Findings for Quarter Milk Samples}

In none of the tested milk samples pathogenic bacteria could be shown, i.e. all quarters were healthy during the study period. It is known that the milk of a healthy udder is sterile and it is only contaminated with bacteria when the milk passes through the teat canal to the outside [9]. Moreover, Johnson, et al. [12] found the same results and reported that a high number of non-lactating dromedary glands are either sterile or harbor only a low number of mainly non-mastitis pathogens. The main reason that most udders remain sterile is the implementation of hygienic measures in the farm. However, the mammary gland of dromedaries is protected by a variety of defense mechanisms like innate or specific immunity as well as physiological particularities [12]. Furthermore, dromedary milk itself possesses powerful antibacterial and antiviral proteins $[3,15,16]$. But, in many African and Asian countries not all camels are healthy (apparently healthy), though their milk is sterile and has no pathogenic bacteria. It is shown in many studies that camel milk is a source for many bacteria which may lead to health hazard for men when it is taken raw $[10,17-20]$ because raw camel milk is produced and handled under poor hygienic conditions with high health risk to the consumers [21]. However, in this study there was no contamination to the camel's milk either from the animal itself, the stable, the farmer or the feed, because the hygienic procedures at the research station were ideal. Furthermore, we used sanitized milking machine (ST-C) in this study, which kept the udder clean and healthy. Consequently, the milk remains clean without pathogenic bacteria. Therefore, we recommend the use of the milking machine in camels. Since the contamination with pathogenic bacteria during hand milking is very high as compared to machine milking [22].

\subsection{Camel Milk Parameters}

\subsubsection{Fat Content}

The mean content of fat in camel milk during the study period was $2.92 \pm 0.07 \%$ and it ranged between $2.70 \pm 0.18$ and $3.30 \pm 0.18 \%$. The Figure 1 shows significant $(\mathrm{P}<0.05)$ and continuous increase in fat content in the milk with progress in the milking season until the eighth week of the study. These results are identical with some 
results in the international studies [23-27]. However, fat content of camel milk varies greatly from 2 to $5 \%$ percent in the literature depending on many factors such as weather conditions, stage of lactation, feed, presence of water, country, and milking method [28-30].

Our results showed that the percentage of fat in the camel milk was somewhat low. Perhaps these low levels of fat contents were due to the camel milk samples that were taken in the summer. This results were confirmed by Haddadin, et al. [31] as they had noticed the lowest percentage of fat in August (2.5\%), and a higher percentage in the middle of winter $(3.9 \%)$. Other factors may affect the low fat content in the camel's milk may be due to the fact that animals were milked once daily only. This fact was shown in a study that total solids, fat content, and milk $\mathrm{pH}$ decreased by increasing milking interval, showing the greatest value at 8 -hr intervals and the lowest at 24-hr intervals [32]. Similar results were obtained by Alshaikh and Salah [33] that the organic component of camel milk such as Fat, Protein, Solids-not-fat (SNF) and Lactose decreased with increasing milking intervals and concurrently the secretion rates of milk was decreased. Moreover, the results indicated that the fat content in the milk increased continuously with advanced stage of lactation. This increase was known in all lactating ruminants, so that most of milk components (total solids, TS, fat, protein and Ash) increased at the end of lactation. In addition, always the presence of feed and water also may affect the fat content of camel milk significantly, so that milk fat concentration became higher by increasing the degree of dehydration in the camel [30]. However, Alwan, et al. [27] reported that the rearing conditions were observed to significantly affect some milk components. In our study, the feed was enough and the water was free for the animals during the investigation period and the ambient temperature was between 22 and $27 \mathrm{C}$. Therefore the fat content in the raw camel milk was quite normal Figure 1.

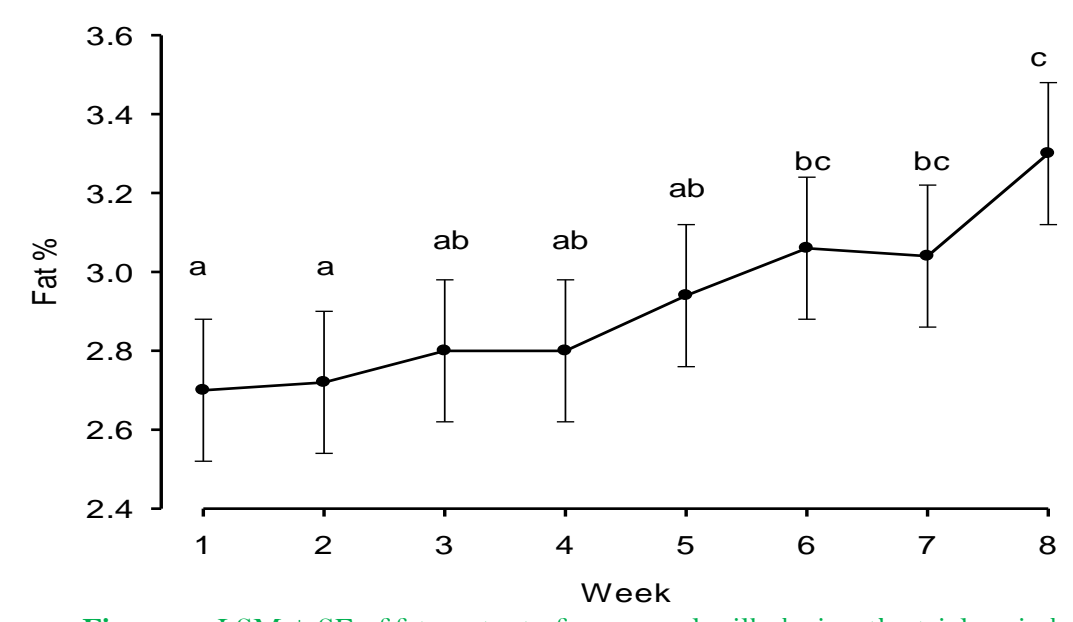

Figure-1. LSM \pm SE of fat content of raw camel milk during the trial period. Means without common letters differ significantly $(\mathrm{P}<0.05)$

Source: Kaskous, S.

\subsubsection{Protein Content}

The mean content of protein in camel milk was $2.28 \pm 0.01 \%$ and it ranged between $2.21 \pm 0.03$ and $2.37 \pm 0.03 \%$. The Figure 2 shows significant $(\mathrm{P}<0.05)$ continuous increase in protein content of the milk with progress in the stage of lactation until the eighth week of the study. The protein content in this study was similar to protein content with other studies as in Ellouze and Kamoun [34] with 2.29\%; Raghvendar, et al. [35] with 2.30\%, but more than the results of Omer and Eltinay [36] with $2.06 \%$. However, the protein content in this study was quite low, compared to the majority of authors as Mal, et al. [37]; Mal, et al. [38] with $3.73 \%$ and 3.89\%, respectively; Bakheit, et al. [39] 3.4\% and the average is $3.1 \pm 0.5 \%$ [40]. In general, the protein percentage of raw camel milk ranges between 2.15 and $4.90 \%$ [41] or between $2.30 \%$ and $3.95 \%$ [1] or between 3 and $3.90 \%[42]$.

On the other hand, this protein content in the milk under German conditions may be normal, since water is free and green forage or hay are available throughout the year. Under these conditions the protein synthesis in the udder was going well. On the contrary, Bekele, et al. [30] reported that, protein content of camel milk is not significantly altered in the presence of water and feed. In general, camel milk contained less protein, fat and lactose than bovine milk [43].

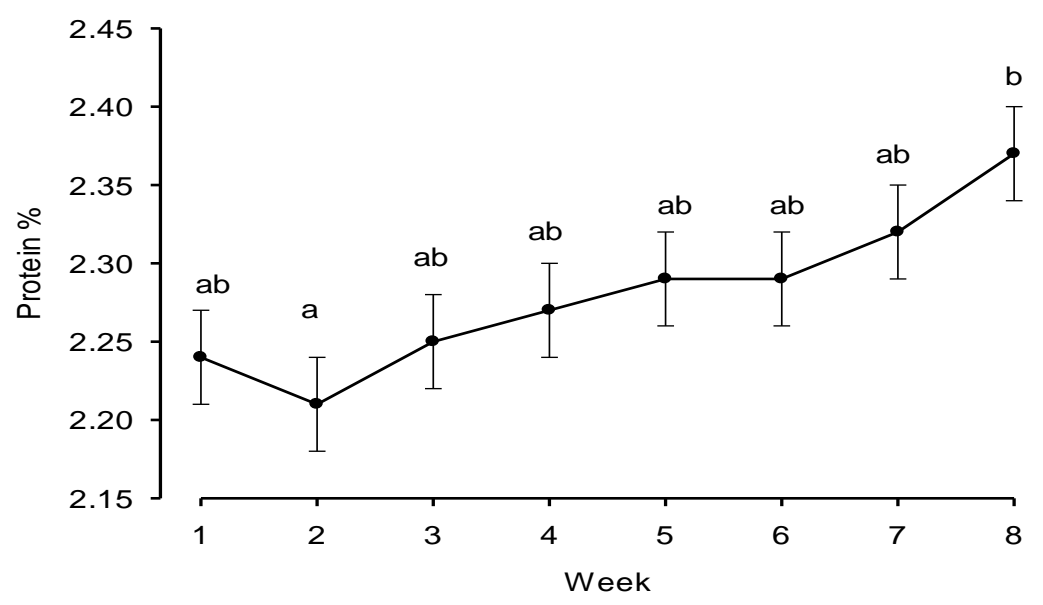

Figure-2. LSM \pm SE of protein content of camel milk during the trial period. Means without common letters differ significantly $(\mathrm{P}<0.05)$

Source: Kaskous, S. 


\subsubsection{Lactose Content}

The mean content of lactose in camel milk was $3.91 \pm 0.02 \%$ and it ranged between $3.81 \pm 0.04$ and $4.04 \pm 0.04 \%$. The Figure 3 shows significant $(\mathrm{P}<0.05)$ and continuous decrease in lactose content in the milk with the progress in the lactation stage until the eighth week of the study. It shows that the lactose content of camel milk is slightly lower than cow's milk with 4.9\%. Similar results were also reported by Elamin and Wilcox [44]. The continuous reduction of the lactose content in the milk in this study was normal, since all the camels reached the end of lactation, then. This process is not only limited to camels, but also with all the lactating ruminants. However, many researchers reported that lactose content of camel milk varied between too extreme values 2.4 and $5.8 \%$ as compared to 4.4 and 5.8 percent in cow's milk [41] and the average was $4.4 \pm 0.7 \%$ [40]. It is known that the lactose content in the milk in true ruminants remains constant, since the lactose content of the milk plays an important role for the osmotic pressure of the mammary gland. Therefore the lactose content of the milk remains unchanged. But the climate and feeding situation of camels are extremely different, therefore slight changes in the lactose content of camel milk was found in different parts of the world $[31,45,46]$ and the nature of vegetation eaten by the camels in the desert areas could play a significant factor in the variation of lactose content in camel milk [42].

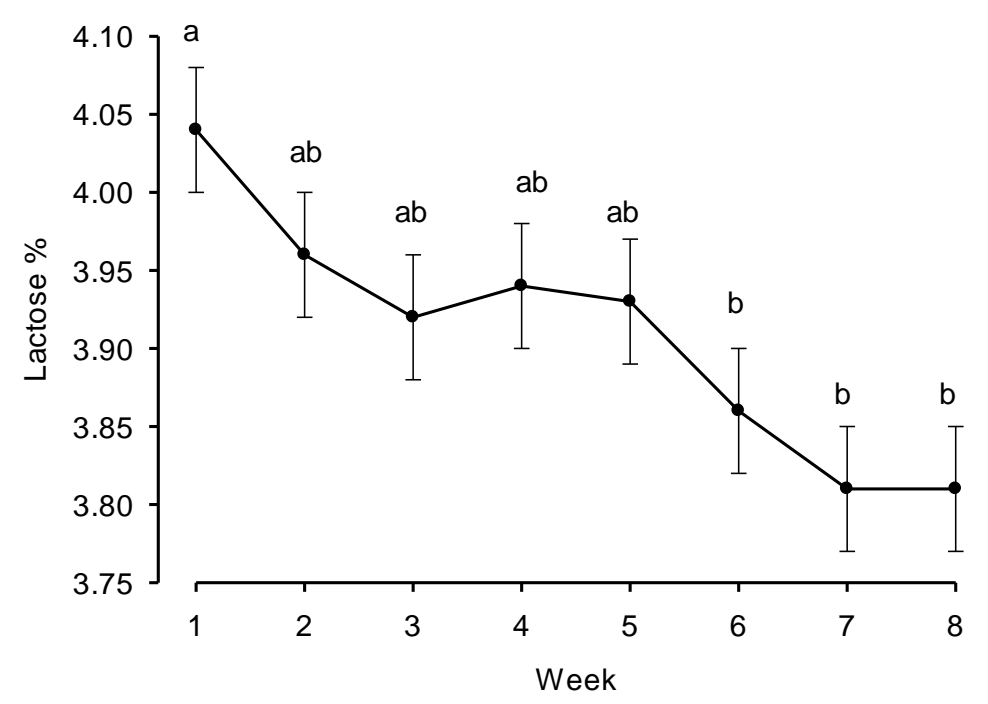

Figure-3. $\mathrm{LSM} \pm \mathrm{SE}$ of lactose content of camel milk during the trial period. Means without common letters differ significantly $(\mathrm{P}<0.05)$

Source: Kaskous, S.

\subsubsection{SCC Content}

The mean number of SCC in raw camel's milk was $126.43 \times 10^{3} \pm 7.21$ cells $/ \mathrm{ml}$ and it ranged between $83.00 \mathrm{x}$ $10^{3}$ and $178.00 \times 10^{3}$ cells $/ \mathrm{ml}$. Similar results have been obtained by Saleh and Faye [47] and the mean value of SCC was $125 \times 10^{3}$ cells $/ \mathrm{ml}$ camel milk. The Figure 4 shows the significant $(\mathrm{P}<0.05)$ differences in SCC content in the milk during the study period. However, the concentration of SCC in the raw camel's milk was normal under German conditions and within the physiological level. Hence, no mastitis could be detected either in clinical or subclinical analysis in the camels, as was written above. It is known that SCC of the milk has been an indicator of the udder health. According to Abdurahman [48] SCC in raw camel's milk were composed of macrophages, polymorphonuclear neutrophil granulocytes $(\mathrm{PMN})$ and lymphocytes. In addition to those cells, a large number of cell fragments can be found in camel milk. These particles may have an influence on the diagnostic of udder health by determining the SCC, as they could be counted with the somatic cells of the immune system. The cell count of a healthy cow udder has not been more than $100 \times 10^{3}$ cells $/ \mathrm{ml}$. However, it has not been known value for the cell number in the healthy camel milk. Therefore, a limit between healthy and sick udder based on the cell count in the milk in camels has not yet been established, because there has been a problem knowing the basal levels of cells and their physiological variations in the camel, until now. Furthermore, investigations have clearly shown that, quarters infected with bacteria had higher mean values for SCC than non-infected quarter [47] and in inflamed quarter's polymorph nuclear granulocytes dominated the sample and in non-inflamed quarters the dominant cells were epithelial cells and cell fragments [49]. However, an increase in the number of SCC, particularly polymorphonuclear neutrophil granulocytes in camel milk is a strong indication of inflammation. This has been the same reaction as in the cow when the udder is inflammated. Interestingly enough, Hamed, et al. [50] found that lymphocytes were the predominant cell type in camel's milk and macrophage in cow's milk, when the cell counts are less than 100.000 cells/ml milk. Furthermore, in raw camel's milk PMN numbers were higher immediately after parturition and declined gradually with advanced lactation, while macrophages number increased through lactation. In cow's milk, PMN were the dominant cell type at the beginning of the lactation and tended to maintain at high levels as lactation progressed. However, limits must be laid down for assessing the state of udder health.

Nagy, et al. [25] reported that the mean of SCC in camel milk tank was $394 \times 10^{3}$ cells $/ \mathrm{ml}$ and it ranged between $113.702 \times 10^{3}$ and $927.423 \times 10^{3}$ cells $/ \mathrm{ml}$. However, most of the milk samples $(75 \%)$ have higher cell numbers (between 300 to $500 \times 10^{3}$ cells $/ \mathrm{ml}$ ) compared to our results. The study acknowledges that, the collected camel milk samples for the SCC determination were obtained from both the entire Herd (Tank milk) over 2 year period and not from a short period as in this study. Perhaps such reason showed the high cell count difference in the camel milk in that study, Moreover, the animals were on a farm in the United Arab Emirates (UAE). Another Studies, explored that the cell count in the camel milk was high as in Woubit, et al. [51] with a range from $3 \times 10^{5}$ to $1.5 \times 10^{7}$ leukocytes $/ \mathrm{ml}$ of camels milk and in Guliye, et al. [52] with a range from $1.01 \times 10^{5}$ to $11.78 \times 10^{6}$ cells $/ \mathrm{ml}$ camel milk.

Surely enough under the Asian and African conditions the cell number in the camel milk was higher than the ones in Europe, and a good hygienic conditions were difficult to achieve due to their high temperature and lack of 
laws and regulations as compared in Europe. Therefore, Abdurahman [49] has concluded that early problem recognition with improved hygienic measures, will result in reduced milk losses due to mastitis hence, increase the availability of milk for human consumption and sale.

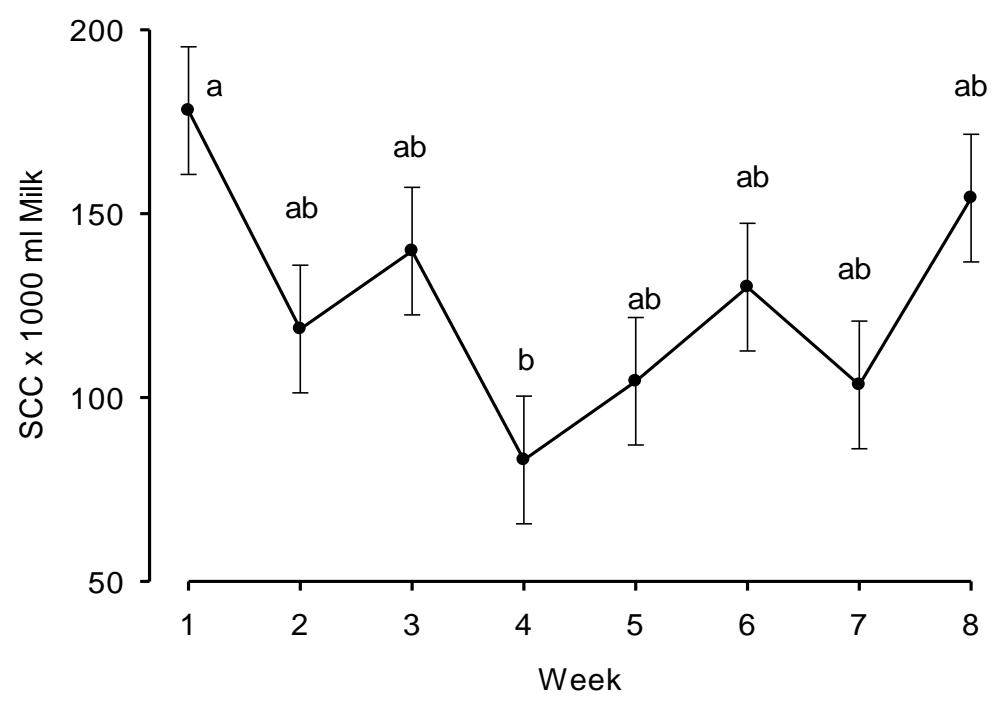

Figure-4. LSM \pm SE of somatic cell count of camel milk during the trial period. Means without common letters differ significantly $(\mathrm{P}<0.05)$ Source: Kaskous, S.

\subsubsection{BC Content}

The mean number of $\mathrm{BC}$ in raw camel milk was $23.88 \times 10^{3} \pm 0.57 \mathrm{BC} / \mathrm{ml}$ and it ranged between $21.00 \times 10^{3}$ and $26.00 \times 10^{3} \mathrm{BC} / \mathrm{ml}$. Figure 5 shows the differences $(\mathrm{P}>0.05)$ in $\mathrm{BC}$ content in the milk during the study period. It was found that the non-pathogenic bacteria number in the camel milk was normal during the course of the experiment, and the udders were healthy, too. Nevertheless, the milk was contaminated with non-pathogen bacteria after milking process. However, in the literature, it has been little information available on the total bacterial number in the raw camel's milk, and the authors did not directly measure the total bacteria count. Bacteriological examinations (blood agar) were carried out as standard methods as mentioned in some studies like Abdurahman, et al. [53]; Woubit, et al. [51]; Yam, et al. [54] and Abera, et al. [6]. However, Ayadi, et al. [55] examined the total flora in the camel milk $\left(32,097 \times 10^{3} \pm 396 \mathrm{ufc} / \mathrm{ml}\right)$, and the camels were healthy by the California Mastitis Test (CMT) during the investigation period.

Abdurahman, et al. [53] reported that $43.5 \%$ of the quarter camel milk samples yielded pathogenic bacteria in Sudan. Streptococcus agalactiae, Streptococcus aureus, coagulase-negative staphylococci, and Escherichia coli were isolated from these milk samples. Other studies of Younan, et al. [56] in Kenya showed that $12 \%$ of camel's milk samples were contaminated with S. agalactiae and $11 \%$ with S. aureus. While Aljumaah, et al. [57] found that 33 $\%$ of the tested quarters had subclinical mastitis based on California mastitis test. But, Abera, et al. [58] have shown that clinical and subclinical mastitis was prevalent to $8.3 \%$ and $20.7 \%$ on the studied camel herd in Ethiopia, respectively. It was concluded from many investigations that improvement in the hygienic measures must be applied in the farms in order to keep udders healthy and milking machine must be applied too to make a good milk quality and the udder remains healthy. It is known that by the application of milking machine in the camel the somatic cell counts in the milk and the microbiological contamination can be significantly reduced as compared to the hand milking [22]. Finally, two points must be emphasized, the milking machine availability and the hygienic measures taken in the farm which, would improve the udder health of the camel, hence the resulting milk quality. In order to confirm this point, Aljumaah, et al. [57] reported that poor hygiene of milking process had a higher prevalence of subclinical mastitis and intramammary infections. Therefore the poor hygiene during milking is identified as a risk factor for occurrence of mastitis in camel $[59,60]$.

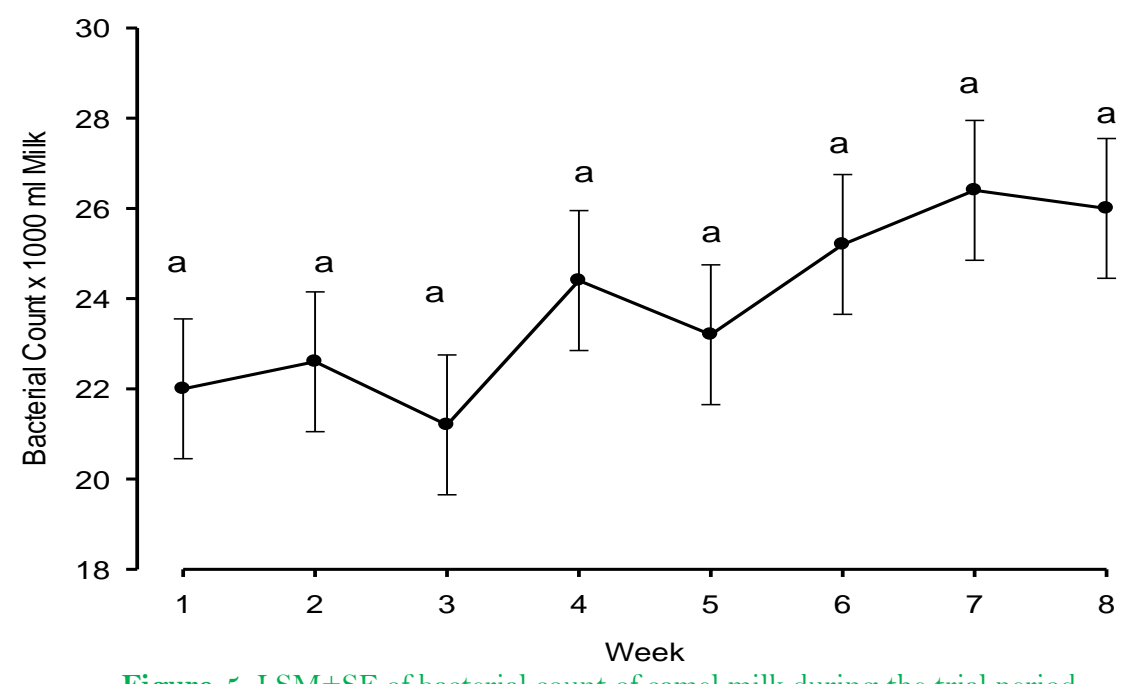

Figure-5. LSM \pm SE of bacterial count of camel milk during the trial period. Means without common letters differ significantly $(\mathrm{P}<0.05)$

Source: Kaskous, S 
According to most authors the composition of camel milk varies greatly and this variation could be attributed to many factors such as rearing conditions [27, 61] season [31] management systems [62] geographical location, feeding regime, breeds or camel types [63] milking frequency [32, 64] stage of lactation and parity [25, 41, 57].

\subsection{Effect of Different of Storage Time and Temperature on Raw Milk Quality}

Statistical analysis has shown that the storage time and temperature have influenced on the camel milk parameters. Table 2 clearly shows the significant $(\mathrm{P}<0.001)$ effect of the storage time on the parameters of fat, Protein, lactose, SCC and BC in the camel milk. The temperature of the milk during storage also had an effect on the camel milk parameters, too. However, the table reveal that, the temperature had a significant $(\mathrm{P}<0.001)$ effect on protein, lactose, SCC and $\mathrm{BC}$, but not on fat content of camel milk. Additionally, the interaction between storage time and temperature has shown a great effect on protein, lactose, SCC and BC Table 2.

\begin{tabular}{|c|c|c|c|c|c|c|c|c|c|c|c|c|}
\hline \multirow[t]{2}{*}{ Effect } & \multirow{2}{*}{$\begin{array}{l}\text { NR } \\
\text { DF }\end{array}$} & \multirow{2}{*}{$\begin{array}{c}\text { DEN } \\
\text { DF }\end{array}$} & \multicolumn{2}{|c|}{ Fat } & \multicolumn{2}{|c|}{ Protein } & \multicolumn{2}{|c|}{ Lactose } & \multicolumn{2}{|c|}{ SCC $* * * *$} & \multicolumn{2}{|c|}{ BC粎** } \\
\hline & & & F Value & $\operatorname{Pr}>\mathbf{F}$ & F Value & $\operatorname{Pr}>\mathbf{F}$ & F Value & $\operatorname{Pr}>\mathbf{F}$ & F Value & $\operatorname{Pr}>\mathbf{F}$ & F Value & $\operatorname{Pr}>\mathrm{F}$ \\
\hline $\mathrm{T}^{*}$ & 4 & 36 & 8.63 & $\mathrm{P}<0.001$ & 36.70 & $<0.001$ & 69.08 & $<0.001$ & 42.77 & $<0.001$ & 739.32 & $<0.001$ \\
\hline TM* & 1 & 36 & 0.71 & 0.4064 & 103.74 & $<0.001$ & 102.86 & $<0.001$ & 114.31 & $<0.001$ & 1346.59 & $<0.001$ \\
\hline TxTM & 4 & 36 & 0.15 & 0.9618 & 77.84 & $<0.001$ & 62.15 & $<0.001$ & 44.62 & $<0.001$ & 652.12 & $<0.001$ \\
\hline
\end{tabular}

Table 3 shows the chemical characteristics of camel milk stored at room temperature $\left(24 \pm 1.7 \mathrm{C}^{\circ}\right)$. Fat, protein, $\mathrm{SCC}$ and $\mathrm{BC}$ contents do not change significantly at room temperature for up to 6 hours and afterwards they had changed significantly $(\mathrm{P}<0.05)$ in 24 and 48 hours of storage. Which confirm that, fat content and SCC in the raw milk were decreased significantly while protein content and BC increased significantly when the raw milk was stored for more than 24 hours at room temperature. Also, lactose content in the milk was decreased significantly $(\mathrm{P}<0.05)$ after 2 hours of storage at room temperature. The results of this study showed that milk quality changed after being stored of 24 hours at room temperature and were completely denatured after storing the milk sample 48 hours at room temperature. Similar results have been found at $+25 \mathrm{C}^{\circ}$ in Algeria in dairy camel milk samples [65]. Contrary to our results, Omer and Eltinay [36] found that the mean values of fat were $2.4,2.7$ and $3.1 \%$ for the $1^{\text {st }}$, $2^{\text {nd }}$ and $3^{\text {rd }}$ days of camel milk stored at room temperature, respectively. The same authors found similar changes to our study in the lactose content of camel milk during storage time at the room temperature, and the mean value of lactose content at room temperature decreased from $4.4 \%$ (day 1) to $3.34 \%$ (day 2) to $3.28 \%$ (day 3 ) in camel milk collection. It seemed that room temperature storage $\left(24 \pm 1.7 \mathrm{C}^{\circ}\right)$ contributed to decrease in milk quality parameters. However, storing the camel milk at room temperature led to significant changes in the total number of microbes in this milk. These changes have led to several physical and chemical alterations in this milk. Therefore, changes in the milk components have occurred. In practice, camel milk mostly stored for 24 hours at room temperature in many countries [66]. After 24 hours storage time, lactic acid bacteria may grow up leading to decrease in the milk pH and at that then camel milk will not be used for human consumption, which we confirmed in this study. Furthermore Omer and Eltinay [36] reported that $\mathrm{pH}$ value in raw camel milk decreased as in our study during the storage time (3 Days) at room temperature, and the mean value of $\mathrm{pH}$ was 6.6 at the day of collection which was reduced to 5.6 ( $2^{\text {nd }}$ day) and to 5.4 ( $3^{\text {rd }}$ day). Another study from Arabha, et al. [67] explored that SCC in the camel milk samples= without adding preservative decreased significantly $(\mathrm{P}<0.0001)$ during 4 days of storage, however, such decrease was not noticed in samples with preservative.

The results on milk samples stored at $+4 \mathrm{C}^{\circ}$ during $0,2,6,24$ and 48 hours showed that lactose content, SCC and $\mathrm{BC}$ were not changed Table 4 . However, it was also found that milk fat and protein contents were lower after being stored at $+4 \mathrm{C}^{\circ}$ during 24 and 48 hours $(\mathrm{P}<0.05)$.

Generally, it can be said that it is possible to store the raw camel milk at room temperature for 24 hours and at $+4 \mathrm{C}^{\circ}$ for 48 hours without noticeable change.

Some studies have shown that when the cow milk was stored at $7 \mathrm{C}^{\circ}$, total bacteria count was increased [65, 68]. However, this increase in bacterial count was reduced when the temperature becomes lower than $+7 \mathrm{C}^{\circ}$. It was reduced further when the storage temperature of the milk samples was decreases to $+4 \mathrm{C}^{\circ}$.

Many farmers from Kazakhstan have sent their camel milk to Moscow, but when this milk arrived, it was no longer tenable or acceptable. That is why the cold chain (not more than 8 degrees) must be applied, starting from the date of collecting the milk from the camel udder until it is reached the consumer.

The average generation time of microorganisms was around 20 to 30 minutes under optimal growth conditions (temperature: 25 to $35 \mathrm{C}^{\circ}$ and $\mathrm{PH} 6.65$ ).

\begin{tabular}{|c|c|c|c|c|c|c|}
\hline T* (hour) & Fat (\%) & Protein (\%) & Lactose (\%) & $\mathbf{P H}$ & $\mathrm{SCC}^{*} *$ X $10^{3} / \mathrm{ml}$ & BC**** $\mathrm{X} 10^{3} / \mathrm{m}$ \\
\hline $\mathrm{O}$ & $2.70 \mathrm{a}$ & $2.26 \mathrm{a}$ & $4.04 a$ & $6.43 \mathrm{a}$ & $178.00 a$ & $22.00 \mathrm{a}$ \\
\hline 2 & $2.70 \mathrm{a}$ & $2.26 \mathrm{a}$ & $4.03 \mathrm{ab}$ & $6.43 \mathrm{a}$ & $173.00 \mathrm{a}$ & $42.20 \mathrm{a}$ \\
\hline 6 & $2.65 \mathrm{ab}$ & $2.26 \mathrm{a}$ & $4.00 \mathrm{~b}$ & $6.40 \mathrm{~b}$ & $178.00 \mathrm{a}$ & $364.20 \mathrm{a}$ \\
\hline 24 & $2.62 \mathrm{~b}$ & $2.28 \mathrm{a}$ & $3.99 \mathrm{~b}$ & $6.37 \mathrm{c}$ & $140.81 \mathrm{~b}$ & $24620.00 \mathrm{~b}$ \\
\hline 48 & $2.61 \mathrm{~b}$ & $2.57 \mathrm{~b}$ & $3.65 \mathrm{c}$ & $5.57 \mathrm{~d}$ & $104.02 \mathrm{c}$ & $63100.00 \mathrm{c}$ \\
\hline SE***** & 0.12 & 0.05 & 0.03 & 0.01 & 7.03 & 742.00 \\
\hline
\end{tabular}

Least Square Means in the same column with different superscripts a, b, c, d are statistically significant different at $\mathrm{p}<0.05$. 
Table-4. Raw camel milk quality after being stored in the refrigerator at $+4 \mathrm{C}^{\circ}$ during $0,2,6,24$ and 48 hours $(\mathrm{T})$ after milking

\begin{tabular}{c|c|c|c|c|c|c}
\hline T* (hour) & Fat (\%) & Protein (\%) & Lactose (\%) & PH & SCC $* * \mathbf{X ~ 1 0}^{\mathbf{3}} / \mathbf{m l}$ & $\mathbf{B C}^{*} * * \mathbf{X ~ 1 0} / \mathbf{m l}$ \\
\hline 0 & $2.70^{\mathrm{a}}$ & $2.26^{\mathrm{a}}$ & 4.04 & 6.43 & 178.00 & 22.00 \\
\hline 2 & $2.67^{\mathrm{a}}$ & $2.26^{\mathrm{a}}$ & 4.04 & 6.43 & 177.20 & 35.40 \\
\hline 6 & $2.64^{\mathrm{ab}}$ & $2.28^{\mathrm{a}}$ & 4.02 & 6.43 & 178.20 & 49.00 \\
\hline 24 & $2.62^{\mathrm{b}}$ & $2.22^{\mathrm{b}}$ & 4.04 & 6.42 & 179.00 & 221.00 \\
\hline 48 & $2.58^{\mathrm{b}}$ & $2.20^{\mathrm{b}}$ & 4.03 & 6.42 & 178.40 & 2099.80 \\
\hline SE** $^{*} * *$ & 0.12 & 0.05 & 0.03 & 0.01 & 7.03 & 742.00 \\
\hline
\end{tabular}
$\mathrm{p}<0.05$.

Least Square Means in the same column with different superscripts a, b are statistically significant different at

\section{Conclusion}

- Healthy and safe camel milk with normal composition can be obtained, since the hygienic measures in the farm are maintained and a milking machine could be used for the milk removal.

- A healthy clean udder is a sterile udder and May produces milk free of pathogens germs.

- It is possible to store the raw camel milk for 24 hours at room temperature and for 48 hours at the refrigerated temperature without any significant change in the milk quality.

- The rapid cooling of raw camel milk after milking process may keep the milk quality in good condition, which may help the farmer to market the raw camel milk safely. However, the hygienic measures in the tropic and subtropical countries are not always available and most camel owners milk their camels with hand.

- Using milking machines "StimuLactor" for camel's guarantees to supply the market with healthy and high quality camel milk.

\section{References}

[1] A. K. Yadav, R. Kumar, L. Priyadarshini, and J. Singh, "Composition and medicinal properties of camel milk: A Review," Asian Journal of Dairy and Food Research, vol. 34, pp. 83-91, 2015. Available at: https://doi.org/10.5958/0976-0563.2015.00018.4.

[2] S. Kaskous, "Importance of camel milk for human health," Emirates Journal of Food and Agriculture, vol. 28, pp. 158-163, 2016. Available at: https://doi.org/10.9755/ejfa.2015-05-296.

[3] S. Kaskous and M. W. Pfaffl, "Bioactive Properties of Minor Camel Milk Ingredients-An Overview," Journal of Camel Practice and Research, vol. 24, pp. 15-26, 2017. Available at: https://doi.org/10.5958/2277-8934.2017.00003.0.

[4] Y. Mehari, Z. Mekuriaw, and G. Gebru, "Potentials of camel production in Babilie and Kebribeyah woredas of the Jijiga Zone, Eastern Ethiopia," in ESAP Proceedings, 2007.

[5] J. Matofari, "Analysis of microbial quality and safety of camel (Camelus Dromedarius) milk chain and implications in Kenya," Journal of Agricultural Extension and Rural Development, vol. 5, pp. 50-54, 2013.

[6] Y. T. Abera, B. Legesse, B. Mummed, and B. Urga, "Bacteriological quality of raw camel milk along the market value chain in Fafen zone, Ethiopian Somali regional state," Biomed Central Research Notes, vol. 9, pp. 285-290, 2016. Available at: https://doi.org/10.1186/s13104-016-2088-1.

[7] L. W. Mwangi, J. W. Matofari, P. S. Muliro, and B. O. Bebe, "Hygienic assessment of spontaneously fermented raw camel milk (suusa) along the informal value chain in Kenya," International Journal of Food Contamination, vol. 3, pp. 18-26, 2016. Available at: https://doi.org/10.1186/s40550-016-0040-8.

[8] B. Serda, A. Bekele, and D. Abebe, "Prevalence and contamination level of staphylococcus aureus in raw Camel Milk and Associated Risk Factors in Jigjiga District, Eastern Ethiopia," Journal of Veterinary Science and Technology, vol. 9, pp. 501-505, 2018. Available at: https://doi.org/10.4172/2157-7579.1000501.

[9] P. Zangerl, Dairy microbiology In: V. Krömker, Short Textbook Milk Dairy and Milk Hygiene 2007 Parey, MVS Medicine Verlag Stuttgart: Medical Publishes Stuttgart, 2007.

[10] S. Kaskous, "Prevalence of microbes in raw camel milk-an overview," IOSR Journal of Agriculture and Veterinary Science, vol. 12, pp. 51-60, 2019.

[11] M.-L. De Buyser, B. Dufour, M. Maire, and V. Lafarge, "Implication of milk and milk products in food-borne diseases in France and in different industrialised countries," International Journal of Food Microbiology, vol. 67, pp. 1-17, 2001. Available at: https://doi.org/10.1016/s0168-1605(01)00443-3.

[12] B. Johnson, M. Joseph, S. Jose, S. Jose, J. Kinne, and U. Wernery, "The microflora of teat canals and udder cisterns in non-lactating dromedaries," Journal of Camel Practice and Research, vol. 22, pp. 55-59, 2015. Available at: https://doi.org/10.5958/22778934.2015.00008.9.

[13] Siliconform Company, "StimuLactor for camels, ST-C, Türkheim, Germany," 2018.

$[14] \quad$ SAS Institute, "Mannnual, version 8 Cary NC, USA," 1999.
$15] \quad$ I. El Sayed, R. Ruppanner, A. Ismail, C. P. Champagne, and R. Assaf, "Antibacterial and antiviral activity of camel milk protective proteins," Journal of Dairy Research, vol. 59, pp. 169-175, 1992. Available at: https://doi.org/10.1017/s0022029900030417.

[16] E. M. El-Fakharany, N. Abedelbaky, B. M. Haroun, L. Sanchez, N. A. Redwan, and E. M. Redwan, "Anti-infectivity of camel polyclonal antibodies against hepatitis C virus in Huh 7.5 hepatoma," Virology Journal, vol. 9, pp. 201-211, 2012. Available at: https://doi.org/10.1186/1743-422x-9-201

[17] E. G. A. Abdel, G. Hildebrandt, J. Kleer, B. Molla, M. Kyule, and M. Baumann, "Comparison of California Mastitis Test (CMT), Somatic Cell Counts (SCC) and bacteriological examinations for detection of camel (Camelus dromedarius) mastitis in Ethiopia," Berliner und Munchener tierarztliche Wochenschrift, vol. 119, pp. 45-49, 2006.

[18] R. H. Omer and A. H. Eltinay, "Microbial quality of camel's raw milk in central \& Southern regions of United Arab Emirates," Emirates Journal of Food \& Agriculture, vol. 20, pp. 76-83, 2008. Available at: https://doi.org/10.9755/ejfa.v20i1.5182.

[19] A. Abeer, A. Gouda, H. Dardir, and A. Ibrahim, "Prevalence of some milk borne bacterial pathogens threatening camel milk consumers in Egypt," Global Vet, vol. 8, pp. 76-82, 2012.

[20] A. E. Elhaj, S. A. B. Freigoun, and T. T. Mohamed, "Aerobic bacteria and fungi associated with raw camel's milk," Journal of Animal and Feed Research, vol. 4, pp. 15-17, 2013.

[21] M. El-Ziney and A. Al-Turki, "Microbiological quality and safety assessment of camel milk (Camelus dromedaries) in Saudi Arabia (Qassim region)," Applied Ecology and Environmental Research, vol. 5, pp. 115-122, 2007. Available at: https://doi.org/10.15666/aeer/0502_115122.

[22] S. K. Saleh and B. Faye, "Detection of subclinical mastitis in dromedary camels (Camelus dromedaries) using somatic cell counts, California mastitis test and udder pathogen," Emirates Journal of Food ङ Agriculture, vol. 23, pp. 48-58, 2013.

[23] O. Siboukeur, "Study of camel milk collected locally: physicochemical and microbiological characteristics, skills coagulation," Ph D Thesis in Agricultural Sciences. Institute National Agronomique El-Harrach-Algiers, 2007. 
[24] F. Chethouna, Study of physicochemical, biochemical characteristics and the microbiological quality of pasteurized camel milk, in comparison with raw camel mill: Memory Magisterium in Applied Microbiology. University Kasdi Merbah Ouargla, 2011.

[25] P. Nagy, S. Thomas, O. Marko, and J. Juhasz, "Milk production, raw milk quality and fertility of dromedary camels (Camelus Drmedarius) under intensive management," Hungarian Veterinary Act, vol. 61, pp. 71-84, 2013. Available at: https://doi.org/10.1556/avet.2012.051.

[26] E. Benyagoub, M. Ayat, T. Dahan, and K. Smahi, "Level of control of the hygienic quality of camel milk (Camelus dromedarius) in south west Algeria and its impact on security," Peak Journal of Food Science and Technology, vol. 1, pp. 53-60, 2013.

[27] O. A. Alwan, A. O. Igwegbe, and A. A. Ahmad, "Effects of rearing conditions on the proximate composition of Libyan Maghrebi camels (Camelus Sromedaries) milk," International Journal of Engineering \&̊ Applied Science, vol. 4, pp. 1-6, 2014.

[28] R. A. Hassan, I. E. El Zubeir, and S. Babiker, "Effect of pasteurization of raw camel milk and storage temperature on the chemical composition of fermented camel milk," International Journal of Dairy Science, vol. 2, pp. 166-171, 2007. Available at: https://doi.org/10.3923/ijds.2007.166.171.

[29] H. Labioui, L. Elmoualdi, A. Benzakour, M. El Yachioui, H. Berny, and M. Ouhssine, "Physicochemical and microbiological study of raw milks," Bulletin of the Bordeaux Pharmacy Society, vol. 148, pp. 7-16, 2009.

[30] T. Bekele, N. Lundeheim, and K. Dahlborn, "Milk production and feeding behavior in the camel (Camelus Dromedarius) during 4 watering regimens," Journal of Dairy Science, vol. 94, pp. 1310-1317, 2011. Available at: https://doi.org/10.3 168/jds.2010-3654.

[31] M. S. Haddadin, S. I. Gammoh, and R. K. Robinson, "Seasonal variations in the chemical composition of camel milk in Jordan," Journal of Dairy Research, vol. 75, pp. 8-12, 2008. Available at: https://doi.org/10.1017/s0022029907002750.

[32] M. Ayadi, M. Hammadi, T. Khorchani, A. Barmat, M. Atigui, and G. Caja, "Effects of milking interval and cisternal udder evaluation in Tunisian Maghrebi dairy dromedaries (Camelus dromedarius L.)," Journal of Dairy Science, vol. 92, pp. 1452-1459, 2009. Available at: https://doi.org/10.3168/jds.2008-1447.

[33] M. A. Alshaikh and M. S. Salah, "Effect of milking interval on secretion rate and composition of camel milk in late lactation," Journal of Dairy Research, vol. 61, pp. 45 1-456, 1994. Available at: https://doi.org/10.1017/s0022029900028375.

[34] S. Ellouze and M. Kamoun, "Evolution of the composition of the dromedary milk according to the stage of lactation," Mediterranean Options-Seminar Series, vol. 6, pp. 307-311, 1989.

[35] S. Raghvendar, S. K. Shukla, M. S. Sahani, and C. Bhaka, "Chemical and physicochemical properties of camel milk at different stages of lactation," presented at the International Conference, Saving the Camel and peoples, Livelihoods, Sadri, Rajasthan India, 2004 .

[36] R. H. Omer and A. H. Eltinay, "Changes in chemical composition of camel's raw milk during storage," Pakistan Journal of Nutrition, vol. 8, pp. 607-610, 2009. Available at: https://doi.org/10.3923/pjn.2009.607.610.

[37] G. Mal, D. Suchitra Sena, V. K. Jain, and M. S. Sahani, "Therapeutic value of camel milk as a nutritional supplement for multiple drug resistant (MDR) tuberculosis patients," Journal of Veterinary Medicine, vol. 61, pp. 88-94, 2006.

[38] G. Mal, D. S. Sena, and M. Sahani, "Changes in chemical and macro-minerals content of dromedary milk during lactation," Journal of Camel Practice and Research, vol. 14, pp. 195-197, 2007.

[39] S. A. Bakheit, A. M. Majid, and A. Nikhala, "Camels (Camelus dromedarius) under pastoral systems in North Kordofan, Sudan: Seasonal and parity effects on milk composition," Journal of Camelid Science, vol. 1, pp. 32-36, 2008.

[40] O. A. Al haj and H. A. Al Kanhal, "Compositional technological and nutritional aspects of dromedary camel milk- A review," International Dairy Journal, vol. 20, pp. 811-82 1, 2010. Available at: https://doi.org/10.1016/j.idairyj.2010.04.003.

[41] G. Konuspayeva, B. Faye, and G. Loiseau, "The composition of camel milk: A meta-analysis of the literature data," Journal of Food Composition and Analysis, vol. 22, pp. 95-101, 2009. Available at: https://doi.org/10.1016/j.jfca.2008.09.008.

[42] J. T. Kula and T. Dechasa, "Chemical composition and medicinal values of camel milk," International Journal of Research in BioSciences, vol. 4, pp. 13-25, 2016. Available at: https://doi.org/10.20431/2349-0365.0404002.

[43] M. Smits, T. Huppertz, A. Alting, and J. Kiers, "Composition, constituents and properties of Dutch camel milk," Journal of Camel Practice and Research, vol. 18, pp. 1-6, 2011.

[44] F. Elamin and C. Wilcox, "Milk composition of Majaheim camels," Journal of Dairy Science, vol. 75, pp. 3155-3157, 1992. Available at: https://doi.org/10.3168/jds.s0022-0302(92)78079-5.

[45] M. A. Mehaia, M. A. Hablas, K. M. Abdel-Rahman, and S. A. El-Mougy, "Milk composition of majaheim, wadah and hamra camels in Saudi Arabia," Food Chemistry, vol. 52, pp. 115-122, 1995. Available at: https://doi.org/10.1016/0308-8146(94)p4189-m.

[46] M. Khaskheli, M. Arain, S. Chaudhry, A. Soomro, and T. Qureshi, "Physico-chemical quality of camel milk," Journal of Agriculture and Social Sciences, vol. 2, pp. 164-166, 2005.

[47] S. K. Saleh and B. Faye, "Detection of subclinical mastitis in dromedary camels (Camelus dromedaries) using somatic cell counts, California mastitis test and udder pathogen," Emirates Journal of Food E Agriculture, vol. 23, pp. 48-58, 2011. Available at: https://doi.org/10.9755/ejfa.v23i1.5312.

[48] O. A. S. Abdurahman, "Detection of subclinical mastitis in camels: Relationship between udder infection and inflammatory indicators in milk, Dromadaires et chameaux, animaux laitiers/ Dromedaries and camels, milking animal. Actes du colloque 24-26 octobre 1994, Nouakchott, Mauritanie. Montepellier, France, Cirad," pp. 31-34, 1998.

[49] O. A. S. Abdurahman, "Udder health and milk quality among camels in the Errer valley of eastern Ethiopia," Livestock Research for Rural Development, vol. 18, pp. 1-9, 2006.

[50] H. Hamed, A. Gargouri, Y. Hachana, and A. El Feki, "Comparison between somatic cell and leukocyte variations throughout lactation in camel (Camelus Dromedarius) and cow's milk," Small Ruminant Research, vol. 94, pp. 53-57, 2010. Available at: https://doi.org/10.1016/j.smallrumres.2010.06.008.

[51] S. Woubit, M. Bayleyegn, P. Bonnet, and S. Jean-Baptiste, "Camel (\# Camelus dromedarius\#) mastitis in Borena, lowland pastoral area, southwestern Ethiopia," Journal of Livestock and Veterinary Medicine in Tropical Countries, vol. 54, pp. $207-212,2001$.

[52] A. Guliye, C. Van Creveld, and R. Yagil, "Detection of subclinical mastitis in Dromedary camels (Camelus dromedarius) using somatic cell counts and the N-Acetyl-B-D-glucosaminidase test," Tropical Animal Health and Production, vol. 34, pp. 95-104, 2002.

[53] O. Abdurahman, H. Agab, B. Abbas, and G. Aström, "Relations between udder infection and somatic cells in camel (camelus dromedarius) milk," Acta Veterinaria Scandinavica, vol. 36, pp. 423-431, 1995.

[54] B. A. Z. Yam, M. Khomeiri, A. S. Mahounak, and S. M. Jafari, "Hygienic quality of camel milk and fermented camel milk (chal) in Golestan Province, Iran," Journal of Microbiology Research, vol. 4, pp. 98-103, 2014.

[55] M. Ayadi, A. Musaad, R. S. Aljumaah, G. Konuspayeva, and B. Faye, "Evaluation of teat condition and udder health of dairy dromedary camel's machine milked under intensive Saudi Arabian condition," presented at the 4th Conference of the International Society of Camelid research and development/ISOCARD, Almaty, Kazakhstan, 8-12 June, 2015.

[56] M. Younan, Z. Ali, S. Bornstein, and W. Müller, "Application of the California mastitis test in intramammary streptococcus agalactiae and Staphylococcus aureus infections of camels (Camelus dromedarius) in Kenya," Preventive Veterinary Medicine, vol. 51, pp. 307-316, 2001. Available at: https://doi.org/10.1016/s0167-5877(01)00228-8.

[57] R. S. Aljumaah, F. F. Almutairi, M. Ayadi, M. A. Alshaikh, A. M. Aljumaah, and M. F. Hussein, "Factors influencing the prevalence of subclinical mastitis in lactating dromedary camels in Riyadh Region, Saudi Arabia," Tropical Animal Health and Production, vol. 43, pp. 1605-1610, 2011 . Available at: https://doi.org/10.1007/s11250-011-9877-2.

[58] M. Abera, O. Abdi, F. Abunna, and B. Megersa, "Udder health problems and major bacterial causes of camel mastitis in Jijiga, Eastern Ethiopia: Implication for impacting food security," Tropical Animal Health and Production, vol. 42, pp. 341-347, 2010. Available at: https://doi.org/10.1007/s11250-009-9424-6.

[59] I. Tourette, S. Messad, and B. Faye, "Impact of livestock milking practices on the health quality of camel milk in Mauritania," Review of Livestock and Veterinary Medicine in Tropical Countries, vol. 55, pp. 229-233, 2002.

[60] K. Saber, S. Mohammed, and A. Ahmed, "Sanitary conditions of lactating dromedary she-camel environment with special reference to milk quality and subclinical mastitis monitoring," Emirates Journal of Food \& Agriculture, vol. 22, pp. 207-215, 2010. Available at: https://doi.org/10.9755/ejfa.v22i3.4890. 
[61] A. Iqbal, R. A. Gill, and M. Younas, "Milk composition of Pakistani camel (Camelus dromedaries) kept under station/farmer's conditions," Emirates Journal of Agriculture Science, vol. 13, pp. 7-10, 2001. Available at: https://doi.org/10.9755/ejfa.v12i1.5197.

[62] I. Dowelmadina, I. El-Zubeir, A. Salim, and O. Arabi, "Influence of some factors on composition of dromedary camel milk in Sudan," Global Journal of Animal Scientific Research, vol. 2, pp. 120-126, 2014.

[63] B. Faye, G. Konuspayeva, S. Messad, and G. Loiseau, "Discriminant milk components of Bactrian camel (Camelus bactrianus), dromedary (Camelus dromedarius) and hybrids," Dairy Science \&5 Technology, vol. 88, pp. 607-617, 2008. Available at: https://doi.org/10.1051/dst:2008008.

[64] M. Hammadi, M. Atigui, M. Ayadi, A. Barmat, A. Belgacem, G. Khaldi, and T. Khorchani, "Training period and short time effects of machine milking on milk yield and milk composition in Tunisian Maghrebi camels (Camelus dromedarius)," Journal of Camel Practice and Research, vol. 17, pp. 1-7, 2010.

[65] A. Sboui, T. Khorchani, M. Djegham, and O. Belhadj, "Comparison of the physicochemical composition of camelin and bovine milk from southern Tunisia; Variation in pH and acidity at different temperatures," Afrique Science, vol. 5, pp. 293-304, 2009.

[66] V. Millogo, M. Sissao, A. A. G. Sidibe, and G. A. Ouedraogo, "Effect of storage time and temperature on raw milk composition of dairy cattle in tropical conditions," African Journal of Dairy Farming and Mill Production, vol. 2, pp. 104-108, 2015.

[67] N. H. Arabha, A. Niasari-Naslaji, A. Atakpour, S. Ghaffari, A. Barin, H. Samiei, M. Amjadi, A. Moradlou, A. Salimi, and I. Narimani, "Preservation of camel milk for somatic cell count and bacteriological investigation," Journal of Camel Practice and Research, vol. 20, pp. 39-43, 2013.

[68] B. Faye and G. Loiseau, "Sources of contamination in dairy sectors and examples of quality approaches," in Proceedings of the International Workshop, CIRAD-FAO, 11-13 December 2000, Montpellier, France, 2000, p. 5. 